освіта в навчальних закладах України: стан, напрямки й перспективи розвитку: XXI Всеукр. наук.-практ. конф. (Кіровоград, 21-23 травня 2015 року) : [матеріали конференції].Кіровоград : КДПУ ім В. Винниченка, 2015. - С. 158-163. 6. Титаренко А. А. Формирование здорового образа жизни у студенческой молодежи / А. А. Титаренко // Актуальні проблеми медико-біологічного забезпечення фізичної культури, спорту та реабілітації : I Міжн. наук.практ інтер.-конф. (Харків, 23 квітня 2015 року): [збірник доповідей]. - Харків : ХДАФК, 2015. - C. 173-176.

УДК $37.013 .42(075.8)$

Екатерина Беляева

\title{
ИССЛЕДОВАНИЕ ГОТОВНОСТИ БУДУЩИХ СОЦИАЛЬНЫХ ПЕДАГОГОВ К СОЦИАЛЬНО-ПЕДАГОГИЧЕСКОМУ СОПРОВОЖДЕНИЮ ОДАРЕННЫХ ШКОЛЬНИКОВ
}

Беляєва К. Ю. Дослідження готовності майбутніх соціальних педагогів до соціальнопедагогічного супроводу обдарованих школярів.

У статті розглянуто основні положення про використання діагностичного інструментарію для дослідження готовності майбутніх соціальних педагогів до соціальнопедагогічного супроводу здібних учнів та засобів її формування, вказано основні методики й результати дослідження, проведеного зі студентами ВНЗ.

Ключові слова: соціальний педагог, соціально-педагогічний супровід, діагностика, готовність.

Беляева К. Ю. Исследование готовности будущих социальных педагогов к социальнопедагогическому сопровождению одаренных школьников.

В статье рассмотрены основные положения о использовании диагностического инструментария для исследования готовности будущих социальных педагогов к сопровождению одаренных учеников и средства ее формирования, указаны основные методики и результаты исследования, проведенного со студентами вузов.

Ключевые слова: социальный педагог, социально-педагогическое сопровождение, диагностика, готовность.

Belyaeva K. Yu. The study of future social teachers' readiness for social and educational support of gifted pupils.

The article deals with the basic statements about the use of diagnostic tools to identify the readiness of the future social teachers to support gifted pupils and means of its formation. The basic techniques and results of the study carried out with university students are given.

Key words: social teacher, social and educational support, diagnostics, readiness.

На современном этапе развития общества приоритетным заданием в системе высшего образования остается качественная подготовка будущих социальных педагогов, умеющих эффективно организовывать свою деятельность, осуществлять сопровождение одаренных школьников, их окружения, создавать условия для раскрытия талантов и способностей ребенка, поддержки его на государственном уровне. При этом важно учесть, что рост потребности общества в квалифицированных специалистах, способных влиять на решение социальных проблем, вызывает необходимость их профессиональной подготовки. 
Важнейшим этапом в подготовке специалистов является подбор необходимого диагностического матеріал ёа для выявления уровня готовности будущих социальных педагогов к осуществлению профессиональной деятельности и проверки эффективности использованных средств формирования их готовности к выполнению различных видов деятельности.

Анализ психолого-педагогической литературы по проблеме диагностирования готовности будущих специалистов социальной сферы к осуществлению профессиональной деятельности показал, что изучены такие ее аспекты: методы совершенствования диагностических исследований образовательного процесса (Н. Чегодаев, В. Царьков, Д. Царькова), диагностика профессионально значимых личностных качеств будущих социальных педагогов (Л. Кобышева). Наряду с этим отмечается недостаточная разработка вопроса о диагностике готовности социальных педагогов к осуществлению основных видов их профессиональной деятельности, средств повышения готовности специалистов к основным видам работы.

В последнее время наблюдается смещение акцента со стороны негативных аспектов жизни на обеспечение развития сильных сторон личности, ее творческого потенциала, талантов и возможностей. Интерес к исследованиям, посвященным развитию одаренности, вызван практической необходимостью в определении факторов внутреннего равновесия и развития личности, ее адекватной самореализации. На наш взгляд, эти факторы могут быть сформированы с помощью социально-педагогического сопровождения ребенка в учебной среде.

Анализ проблем социализации одаренных школьников позволил сделать вывод, что одаренные школьники относятся к категории детей, которые требуют внимания со стороны социального педагога, а его профессиональная деятельность по организации их социального сопровождения будет способствовать формированию адекватного отношения окружающих к их успехам, уменьшению конфликтных ситуаций и недоразумений, которые возникают в результате ускоренного развития одаренного ребенка. Это дает основание считать, что одной из актуальных проблем подготовки будущих социальных педагогов является разработка диагностического инструментария для выявления уровня готовности будущих социальных педагогов к социальному сопровождению одаренных школьников.

Как отмечает С. Карпова, «в процессе социализации в современном обществе одаренный ребенок испытывает на себе воздействие таких факторов риска, как: стресс, эмоциональная незрелость, выраженность поведенческих и эмоционально-волевых нарушений, неуверенность в себе, тревожность в ситуациях межличностного взаимодействия, что приводит к появлению неуспешности социальных контактов со сверстниками, родителями, учителями» [1]. Таким образом, для успешной социализации одаренных школьников и снижения негативного влияния различных факторов на их развитие необходимо, на наш взгляд, организовывать их социально-педагогическое сопровождение.

Анализ исследований О.Ярошевского показал, что наличие адекватного инструментария является обязательным условием объективной диагностики текущего состояния процесса подготовки будущих специалистов и ее последующих этапов [5]. Нами определены такие критерии и показатели подготовки будущих социальных педагогов к социально-педагогическому сопровождению одаренных школьников:

- мотивационно-ценностный (направленность профессиональных интересов на будущую деятельность с одаренными школьниками, мотивационно-ценностное отношение к профессиональной деятельности и решению проблем их социализации через осознание 
необходимости организации социально-педагогического сопровождения одаренных школьников, потребность в профессиональном саморазвитии и самосовершенствовании как необходимое условие эффективного взаимодействия с одаренными учениками);

- когнитивный компонент (знания: по истории исследования проблемы одаренности; о специфике работы социального педагога с одаренными школьниками; об организации социально-педагогического сопровождения одаренных школьников);

- практический компонент (умения: аналитические, коммуникативные, организаторские, мобилизационные, творческие);

- личностный компонент (качества личности: доброжелательность, эмпатия, гуманизм, коммуникабельность). Для прослеживания динамики изменений у будущих социальных педагогов в процессе их профессиональной подготовки нами подобран соответствующий диагностический инструментарий: разработанный нами тест для выявления когнитивной готовности будущих социальных педагогов к социальнопедагогическому сопровождению одаренных школьников, который включает в себя вопросы о понятии одаренности, проблемах социализации одаренных детей, их сопровождении; тест мотивационной структуры личности $\mathrm{B}$. Мильмана, который позволяет выявить мотивационный и эмоциональный профили личности, увидеть направленность интересов студентов для прогнозирования работы с ними в направлении сопровождения одаренных школьников, а также тест на определение направленности личности (В. Смекайл, М. Кучер), определение способности к эмпатии (И. Юсупов) [3].

Использование основных перечисленных методик в ходе пилотажного этапа исследования способствовало созданию целостной картины об уровнях готовности будущих социальных педагогов к сопровождению одаренных учеников, а также отбору эффективного диагностического инструментария для их выявления. Выбор данных методик обусловлен критериями и показателями готовности специалистов к сопровождению одаренных школьников и необходимостью дальнейшего формирования знаний, умений, навыков и опыта работы у социальных педагогов в указанном направлении. Исходя из этого, необходимо назвать базовые понятия, которые должны быть усвоены студентами в процессе их подготовки, а также продиагностировать процесс этого усвоения и применения знаний социальными педагогами на практике.

Так, А. Власова, Е. Цвенгер, М. Червонный, Т. Швалева определяют социальнопедагогическое сопровождение одаренных детей как «взаимосвязанную деятельность всех субъектов сферы образования и других социально ответственных структур, направленную на создание благоприятной образовательной среды, обеспечивающей интеллектуальное обогащение учащихся за пределами школы и способствующей развитию их потенциальных возможностей» [2, с. 250]. Исходя из определения, важнейшим результатом социальнопедагогического сопровождения одаренных школьников является создание благоприятной среды, способствующей развитию потенциальных возможностей. Поэтому от того, насколько будущие социальные педагоги сами нацелены на развитие своего потенциала, необходимого для организации социально-педагогического сопровождения, и будет зависеть их результат взаимодействия с одаренными школьниками. В процессе организации социально-педагогического сопровождения социальный педагог должен помнить о том, что чрезмерное погружение в мир собственных переживаний может вообще привести к замкнутости одаренного школьника, поэтому будущий специалист должен иметь: достаточный уровень мотивации к работе с одаренными школьниками, устойчивый интерес к взаимодействию с ними; владеть знаниями об особенностях и проблемах социализации 
одаренных школьников; придерживаться принципов поликультурности при организации сопровождения одаренных школьников, проявлять терпение к таким ученикам, знать особенности общения с ними.

Таким образом, важно, чтобы у будущего социального педагога, работающего с одаренными детьми, была достаточная мотивация к развитию своих профессиональных умений и навыков. В результате исследования готовности студентов - будущих социальных педагогов во время констатирующего этапа экспериментального исследования, проведенного на базе Харьковского национального педагогического университета имени Г. С. Сковороды, Коммунального заведения «Харьковской гуманитарно-педагогической академии», Харьковской государственной академии культуры, Херсонского государственного университета, обнаружено, что большинство студентов ориентированы на успешное выполнение своей будущей профессиональной деятельности (75\%).

На этапе констатации было выявлено, что у студентов недостаточно сформированы умения, которые необходимы им для организации социально-педагогического сопровождения одаренных школьников, а именно: проявление нетерпимого отношения к людям, которые мыслят нестандартно, выдвигают собственные идеи, которые отличаются от взглядов студентов. Оценка творческих умений студентов осуществлялась в рамках педагогической практики в процессе их взаимодействия с одаренными школьниками. Следовательно, отсутствие подготовки специалистов к организации социальнопедагогического сопровождения одаренных школьников влияет на возникновение трудностей у студентов при определении ими проблем одаренных школьников, их анализа и исследования, незнание основных методик диагностирования проблем адаптации личности.

В ходе проведения формирующего этапа экспериментального исследования нами обнаружена инертность со стороны некоторых студентов к получению новых знаний об одаренных школьниках. В ходе проведения диагностирования студентов IV курса во время тренинговых занятий мы выяснили, что: 50 \% студентов затруднились четко представить характеристику проблем одаренных школьников, воспитывающихся в семьях «группы социального риска», а 60 \% - не охарактеризовали специфику работы социального педагога в специализированном учреждении для одаренных школьников. Полученные результаты свидетельствуют о необходимости использования средств для формирования у студентов знаний о сущности социально-педагогической работы с одаренными школьниками в специализированных учреждениях, об особенностях работы социального педагога с ними. Недостаточно освещенным и научно обоснованным является вопрос организации социальнопедагогического сопровождения одаренных школьников во внешкольной деятельности, много нерешенных проблем остается с организацией их досуга, который отличается своей спецификой и содержательной наполненностью. Дети, у которых выявлены особые способности к обучению, спортивной, художественной деятельности, лідерства, имеют особенности в своем развитии, которое происходит не только во время учебной деятельности, а преимущественно во внеучебной. Исходя из этого, для будущих социальных педагогов был разработан спецкурс [4], в процессе освоения которого студенты смогли более детально ознакомиться с тем, как они могут способствовать решению проблем одаренных школьников, а также то, как это отразится на их профессиональном росте.

Следует отметить, что после проведенных с будущими социальными педагогами тренингов по подготовке их к работе с одаренными школьниками во время педагогической практики в общеобразовательных учебных учреждениях показатели их личностной готовности к социально-педагогическому сопровождению выросли на $27 \%$, а развитие 
умений моделировать решение социально-педагогических ситуаций - на 25 \%. Результаты повторного анкетирования показали, что у студентов повысился не только интерес к работе с данной категорией детей, а также и знания особенностей и проблем их социализации. Важно отметить и то, что студенты научились анализировать проблемные ситуации, возникающие в среде, где учится одаренный школьник. Повышение качества знаний студентов в этом направлении, развитие практических умений способствовало улучшению показателей их мотивации к социально-педагогическому сопровождению одаренных школьников.

Таким образом, необходимыми условиями эффективной подготовки будущих социальных педагогов к социально-педагогическому сопровождению одаренных школьников является не только формирование их готовности к решению социальнопедагогических ситуаций, а также развитие их личностных и профессиональных качеств, коммуникативных и организаторских умений, интереса к работе с одаренными детьми, но и своевременная их диагностика, адекватно выбранные ее методы и средства для повышения готовности социальных педагогов к качественному сопровождению участников учебновоспитательного процесса. Использование педагогического тестирования, психологических стандартизированных методик в процессе подготовки социальных педагогов, прошедших экспертизу, проверенных на валидность и надежность, помогает выявить глубину знаний социальных педагогов, уровень общей осведомленности о профессии социального педагога, а также уровень знаний и сформированность умений, необходимых для работы с одаренными детьми.

\section{Литература}

1. Карпова С. И. Проблема детской одаренности на современном этапе развития отечественного образования: [монографія] / $\quad$ С. И. Карпова. - Одинцово : АНОО «Одинцовский гуманитарный университет», 2008. - 151 с. 2. Модель социального сопровождения интеллектуально одаренных детей в области физики и математики, обеспечивающая им необходимую академическую мобильность / М. А. Червонный, Т. В. Швалева, А. А. Власова, Е. И. Цвенгер // Вестник ТГПУ (TSPU Bullutin). - 2012. - № 7 (122). - С. 250. 3. Яковенко К. Ю. Методичні рекомендації зі спецкурсу «Організація соціально-педагогічного супроводу обдарованих школярів» за вимогами кредитно-модульної системи для студентів денної та заочної форм навчання спеціальності «Соціальна педагогіка» / К. Ю. Яковенко. - Харків : ХНПУ, 2011. - 68 с. 4. Яковенко К. Ю. Методичні матеріали тренінгу «Практичні аспекти підготовки соціального педагога до роботи 3 обдарованими дітьми» / К. Ю. Яковенко. - Харків : ХНПУ, 2010. - 36 с. 5. Ярошенко О. Г. Диагностика профессионально-практической подготовки студентов профессий «человекчеловек» с использованием квалиметрии // Международный журнал экспериментального образования. - 2013. - № 4 - С. 342-344.

УДК $371.13: 372.4$

Наталія Борисенко, Наталія Сидоренко

\section{МОДЕЛЮВАННЯ САМООСВІТНЬОЇ ДІЯЛЬНОСТІ МАЙБУТНЬОГО ВЧИТЕЛЯ ПОЧАТКОВОЇ ШКОЛИ: ДІАГНОСТИЧНИЙ АСПЕКТ}

Борисенко Н. М., Сидоренко Н. І. Моделювання самоосвітньої діяльності майбутнього вчителя початкової школи: діагностичний аспект.

У статті проаналізовано можливості комп'ютерної діагностики самоосвітньої діяльності майбутнього вчителя початкової школи в межах синергетичного підходу, 